\title{
Wyznaczanie korytarzy przewietrzających przy użyciu metody morfometrycznej dla wybranego fragmentu miasta Lodzi
}

\author{
Anna Bochenek, Katarzyna Klemm \\ Instytut Inżynierii Środowiska i Instalacji Budowlanych, \\ Wydział Budownictwa, Architektury i Inżynierii Środowiska, Politechnika Łódzka, \\ e-mail:an.bochenek@wp.pl,katarzyna.klemm@p.lodz.pl
}

Streszczenie: W pracy podjęto próbę wyznaczenia terenów stanowiących potencjalne korytarze przewietrzające warunkujące prawidłowe funkcjonowanie systemu aeracyjnego miasta. Badanie zostało przeprowadzone przy użyciu jednej z najpopularniejszych metod morfometrycznej, ze względu na niski koszt pozyskania danych oraz wysoką precyzję otrzymywanych wyników. Z uwagi na dominujący kierunek napływu wiatru, analizami objęto dowietrzny fragment miasta Łodzi. Pierwszy etap opracowania objął analizę podstawowych parametrów szorstkości terenu, tj. chropowatości podłoża $\left(z_{o}\right)$, przemieszczenia płaszczyzny zerowej $\left(z_{d}\right)$ oraz porowatości w obrębie warstwy dachowej $(P)$. Na podstawie uzyskanych wyników oraz przyjętych kryteriów prawidłowego funkcjonowania korytarzy przewietrzających wyznaczono osiem obszarów swobodnego napływu powietrza do miasta.

Słowa kluczowe: korytarze przewietrzające, metoda morfometryczna, wskaźniki szorstkości podłoża, planowanie przestrzenne, tereny zurbanizowane

\section{Wprowadzenie}

Problematyka prawidłowego kształtowania przepływu powietrza na terenach zurbanizowanych jest przedmiotem badań od XIX wieku. Wtedy ukazały się pierwsze opracowania dotyczące zmian klimatycznych w największych miastach europejskich (Londyn, Paryż, Wiedeń) [1]. Aktualnie tematyka ta nabiera szczególnego znaczenia z uwagi na obserwowane silne antropogeniczne przekształcenia środowiska, przejawiające się zwiększoną emisją zanieczyszczeń, uszczelnieniem podłoża czy zwiększeniem powierzchni zabudowanej. Wzrastająca liczba ludności obszarów zurbanizowanych przyczynia się do degradacji tkanki urbanistycznej, niekontrolowanego sposobu zabudowy, a tym samym modyfikacji elementów klimatycznych (usłonecznienia, temperatury, wilgotności oraz prędkości wiatru) [2]. Skutkiem tego jest powstawanie negatywnych zjawisk, takich jak miejska wyspa ciepła, wynikająca z nadwyżki w bilansie promieniowania cieplnego oraz osłabiona wymiana powietrza spowodowana zwartą strukturą zabudowy. Zjawiska te mają bezpośredni wpływ na jakość życia oraz zdrowie mieszkańców. W kontekście zrównoważonego rozwoju miast koniecznym staje się zagwarantowanie prawidłowych warunków klimatycznych w ich obrębie. Jest to możliwe poprzez kształtowanie systemu cyrkulacji powietrza opartego na korytarzach przewietrzających, stanowiących główne obszary napływu powietrza na tereny zurbanizowane [3]. Niestety często zagadnienia te są pomijane lub traktowane marginalnie w planowaniu przestrzennym. Coraz silniejsza presja inwestorów na atrakcyjne tereny otwarte, zlokalizowane w centrum miasta przesądza o przeznaczeniu ich na cele mieszkaniowe. Zjawiskiem powszechnym stają się nowe inwestycje stopniowo wypełniają- 
ce grunty przeznaczone na korytarze przewietrzające. Nie bez znaczenia jest także słaba znajomość zagadnień oddziaływania zabudowy na przepływ powietrza wśród planistów i urbanistów. W pracy przedstawiono próbę wyznaczenia korytarzy przewietrzających w obrębie zachodniej, dowietrznej części Łodzi za pomocą metody morfometrycznej. Bazując na danych przestrzennych pozyskanych z Łódzkiego Ośrodka Geodezji przeprowadzono analizę zagospodarowania terenu oraz ocenę parametrów szorstkości, tj. przemieszczenia płaszczyzny zerowej, współczynnika szorstkości terenu oraz porowatości w obrębie warstwy dachowej. Określenie tych parametrów pozwoliło na wyznaczenie potencjalnych korytarzy przewietrzających.

\section{Cyrkulacja powietrza w obszarach zabudowanych}

W wyniku znacznej szorstkości powierzchni miasta prędkość wiatru ulega wyraźnemu osłabieniu. Szczegółowe badania klimatu Krakowa wykazały, że osłabienie prędkości wiatru w centrum miasta wynosi średnio 30\%, zmniejszając się w zabudowie osiedlowej strefy zewnętrznej do 15 - 20\%. Obserwuje się jednocześnie zjawisko obniżenia prędkości wiatrów $4-5 \mathrm{~m} / \mathrm{s}$ i wzrost prędkości wiatrów słabych wskutek hiperwentylacji [4]. Zwiększeniu ulega częstotliwość występowania cisz atmosferycznych. Dynamiczne oddziaływanie budynków na przepływ powietrza powoduje również silne deformacje kierunku wiatru. Może on ulegać zmianie od kierunku głównego w zakresie od 10 do 20 stopni. W przypadku Krakowa zgodność kierunków wiatru zanotowana w centrum miasta wynosiła tylko $23 \%$, a w zabudowie osiedlowej dochodziła do 68\% [4].

Modyfikacja pola wiatru nad miastem wynika z różnicy ciśnienia między miastem a obszarem pozamiejskim, wywołanej zmianą gęstości i ciężaru powietrza. Różnica ta związana jest z nadwyżką ciepła w mieście, której źródłami są ciepło promieniowania słonecznego, ciepło zakumulowane przez sztuczną powierzchnię miasta oraz ciepło odpadowe, tracone w procesach technologicznych. W warunkach słabej cyrkulacji atmosfery, przypadającej na okres występowania wiatrów słabych i cisz atmosferycznych, dochodzi do powstania miejskiej wyspy ciepła i związanego z nią systemu wiatrów bryzowych, skierowanych do wnętrza miasta [5],[6]. W warunkach generalnie osłabionego przepływu powietrza w mieście, ciągi komunikacyjne, dna dolin biegnące ze strefy pozamiejskiej do centrum miasta umożliwiają wnikanie do miasta powietrza z obszarów zewnętrznych. Odpowiednio zaplanowane korytarze przewietrzające, o niskiej szorstkości podłoża i dużym udziale zieleni, pełniącej rolę filtrującą i chłodzącą, pozwalają na pozytywne wykorzystanie bryzy miejskiej [7]. Szczegółowe wymagania dotyczące kryteriów, jakie powinien spełniać korytarz przewietrzający określono między innymi w pracy Matzarakisa i Mayera [8]. Najważniejsze z nich przedstawiono poniżej.

1. Minimalna długość korytarza przewietrzającego musi wynosić, co najmniej 1000 m w jednym kierunku.

2. Minimalna szerokość korytarza musi wynosić cztery razy więcej niż wysokość przeszkód bocznych, z zastrzeżeniem, że wartość ta jest nie mniejsza niż $50 \mathrm{~m}$.

3. Wartość parametru szorstkości podłoża $\left(z_{0}\right)$ musi być mniejsza niż $0,5 \mathrm{~m}$.

4. Wartość parametru przemieszczenia płaszczyzny zerowej $\left(z_{d}\right)$ nie powinna przekraczać $3 \mathrm{~m}$.

5. Tereny stanowiące granicę korytarzy powinny być pozbawione przeszkód. Jeśli jest to niemożliwe to:

a) wartość szerokości przeszkody nie może być większa niż 10\% wartości szerokości korytarza,

b) wysokość przeszkody powinna wynosić mniej niż 10 m, 
c) dłuższa krawędź przeszkody powinna być ulokowana równolegle względem osi pasa przewietrzającego,

d) stosunek wysokości do odległości pomiędzy pojedynczymi obiektami może maksymalnie wynosić 0,1 dla obiektów budowlanych oraz 0,2 dla drzew.

\section{Charakterystyka czynników warunkujących powstanie systemu korytarzy przewietrzających w Lodzi}

System przewietrzający Łodzi jest pochodną lokalnych warunków fizjograficznych, układu urbanistycznego, cech klimatycznych regionu oraz zjawisk związanych z funkcjonowaniem miasta. $Z$ jednej strony wymienione czynniki mogą wspomagać przepływ powietrza na terenie miasta, zaś z drugiej stanowić barierę aeracyjną wpływając na pogorszenie jakości życia mieszkańców [9].

Pierwsza z cech - specyficzne ukształtowanie terenu wynikające z położenia pomiędzy terenami Wyżyn oraz Niżu Polskiego, tj. nachylenie z północnego-wschodu na południowy-zachód oraz występujące pasmo Wzniesień Łódzkich powodują zahamowanie napływającego powietrza do miasta [10]. Rozpatrując warunki fizjograficzne Łodzi należy wspomnieć o przekształceniach w sferze gospodarki wodnej. Uszczelnianie oraz regulacja koryt przyczyniła się do zaniku górnych odcinków rzek. Tym samym została zmniejszona liczba powierzchni kontrastowych odpowiadających za intensyfikację procesu wymiany powietrza [11].

Kolejny z czynników - układ urbanistyczny - może znacząco przyczynić się do powstania zwartego systemu korytarzy przewietrzających. Rozwój miasta na osi północpołudnie, wyraźnie zarysowana oś wschód-zachód, prostopadła siatka ulic tworząca szkielet miasta może powodować zwiększenie intensywności wymiany powietrza [12].

Wśród cech klimatycznych regionu należy wymienić kierunek napływu wiatru. W przypadku Łodzi, napływ mas powietrza następuje z sektora zachodniego (W oraz SW) i sektora wschodniego (E oraz SE). Uwzględnienie tego czynnika w procesie projektowania korytarzy przewietrzających może przyczynić się do powstania efektu chłodzącego miasto w porze letniej, a także zapobiegać tworzeniu się dyskomfortu wietrznego mieszkańców w porze zimowej [13].

Ostatni z czynników, tj. zjawisko miejskiej wyspy ciepła jest związane ze wzrostem temperatury $\mathrm{w}$ przyziemnej warstwie atmosfery, w stosunku do terenów peryferyjnych. Wynika ono z nadwyżki w bilansie promieniowania cieplnego, zysków ciepła ze sztucznych źródeł oraz utrudnionej wymiany powietrza ze względu na występującą, zwartą strukturę zabudowy. Powoduje ono powstanie warunków przegrzania miasta, czego skutkiem mogą być poważne problemy zdrowotne mieszkańców [14]. Z drugiej strony odpowiednie wykorzystanie związanej z wyspą ciepła bryzy miejskiej, może przyczynić się do poprawy warunków aeracyjnych miasta.

\section{Zastosowanie metody morfometrycznej w wyznaczaniu parametrów szorstkości terenu}

Najistotniejszy wpływ na przepływ powietrza w sąsiedztwie powierzchni ziemi ma rodzaj opływanego terenu. Szorstkość podłoża uwarunkowana gęstością i rodzajem zabudowy, istnieniem pokrywy roślinnej w istotny sposób kształtuje profil prędkości wiatru. Parametry szorstkości określają jak efektywna jest powierzchnia terenu w transformacji energii przemieszczającego się nad nią wiatru na ruch turbulentny w warstwie brzego- 
wej [15]. Wśród parametrów określających szorstkość powierzchni najczęściej stosowany jest współczynnik szorstkości $z_{o}$ (zwany również parametrem chropowatości lub wysokością chropowatości) oraz wysokość $z_{d}$ zwana przemieszczeniem płaszczyzny zerowej. Określa ona wysokość, na której na skutek odziaływania przeszkód w postaci zabudowy lub drzew wiatr wytraca prędkość do zera. Według Grimmond i Oke [16] [17] istnieją trzy podstawowe metody wyznaczania powyższych wielkości takie jak: mikrometeorologiczna (anemometryczna), wizualnego szacowania oraz morfometryczna. Pierwsza z wymienionych metod bazuje na danych pochodzących z bezpośrednich pomiarów prędkości wiatru, które pozwalają na wyznaczenie pionowych profili jego prędkości wykorzystując wzór logarytmiczny. Niestety jest ona związana z wysokim kosztem pozyskania danych oraz wysoką wrażliwością modelu na błędy danych wejściowych. Metoda wizualnego szacowania polegająca na określeniu stopnia szorstkości terenu według ośmiu klas chropowatości zaproponowanych przez Davenporta (oryginalnie 3 klasy) i zmodyfikowanych przez Wieringa [18] charakteryzuje się małą precyzją otrzymywanych wyników. W odniesieniu do terenów zabudowanych klasyfikacja uwzględnia jedynie dwie klasy szorstkości. Ostatnia z wymienionych metod - morfometryczna - jest najczęściej wykorzystywaną w badaniach korytarzy przewietrzających, ze względu na niski koszt pozyskania danych, wysoką precyzję wyników oraz relatywnie prostą procedurę obliczeniową wykorzystującą Geograficzne Systemy Informacji. Takie podejście zostało wykorzystane między innymi w pracach Gala i Ungera [19] oraz Sudera i Szymanowskiego [20]. W obu przypadkach wyznaczenie terenów umożliwiających swobodny napływ powietrza do miast nastąpiło w oparciu o metodę morfometryczną podzieloną na trzy etapy, tj. pozyskanie danych przestrzennych, wyznaczenie parametrów szorstkości terenu oraz wyznaczenie korytarzy przewietrzających wykorzystując oprogramowanie typu GIS.

Dane pozyskane do opracowań pochodziły z baz cyfrowych jednostek administracji publicznej. Analizy dokonane przez Gala i Ungera na terenie Szeged (Węgry) bazowały na informacjach pozyskanych techniką fotogrametryczną, z których po przetworzeniu powstały cyfrowe bazy danych. Dane wykorzystane w badaniach Sudera i Szymanowskiego na terenie Wrocławia zostały pozyskane techniką teledetekcyjną - skaningiem laserowym (tzw. LIDAR). Autorzy wykorzystali także dostępne ortofotomapy dla miasta.

Kolejny etap badań obejmował pozyskanie danych o wymiarach budynków, tj. wysokości, długości, szerokości. W obu przypadkach problematyczną kwestią było wyznaczenie parametru wysokości obiektów dla nieregularnych grup budynków (np. domów szeregowych, kwartałów zabudowy kamienicznej), ze względu na zwartość struktury zabudowy miast. W celu określenia tej wartości zastosowano formułę, którą w postaci ogólnej można zapisać, jako:

$$
h=\frac{\sum_{\mathrm{i}=1}^{\mathrm{n}} A_{P_{i}} h_{i}}{\sum_{\mathrm{i}=1}^{\mathrm{n}} A_{P_{i}}}
$$

gdzie: $A_{P}$ - powierzchnia obiektu, $h$-wysokość obiektu.

Następnie dla każdego obiektu/grup obiektów zostały wyznaczone powierzchnie: zabudowy $\left(A_{P}\right)$, odniesienia $\left(A_{T}\right)$ oraz frontowa $\left(A_{F}\right)$, zależne od kierunku napływu wiatru. $\mathrm{W}$ dalszym etapie posłużyły one do oszacowania podstawowych współczynników szorstkości terenu tj. szorstkości podłoża $\left(z_{o}\right)$, przesunięcia płaszczyzny zerowej $\left(z_{d}\right)$ oraz porowatości w obrębie warstwy dachowej $(P)$.

Na rys. 1. przedstawiono parametry wejściowe do określenia szorstkości podłoża. 


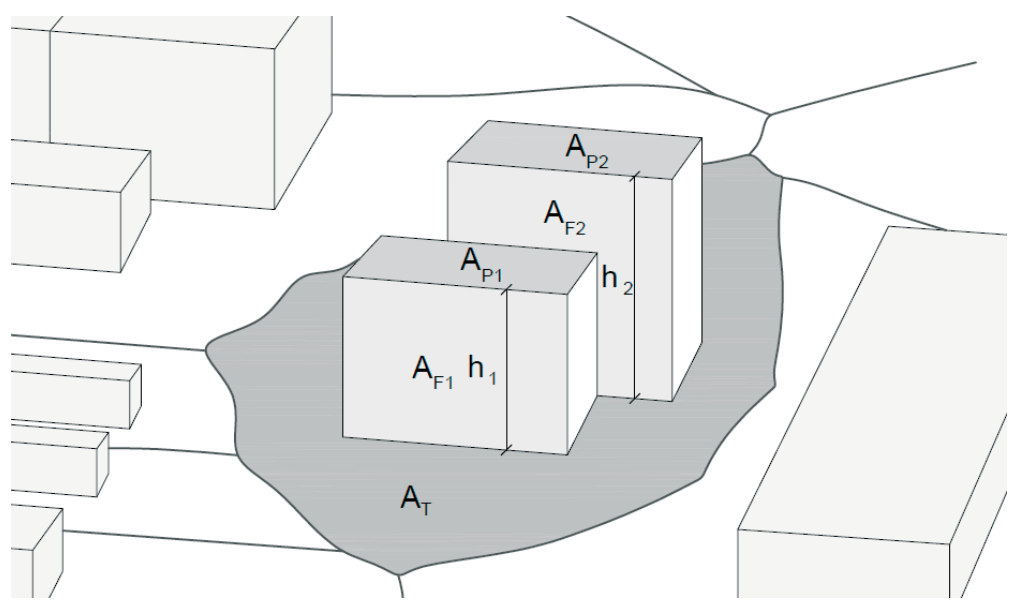

Rys. 1. Parametry wejściowe do określenia współczynnika szorstkości podłoża ( $A_{P}-$ powierzchnia zabudowy, $A_{F}$ - powierzchnia frontowa, $A_{T}$ - powierzchnia odniesienia, $h$ - wysokość obiektu)

Parametr szorstkości podłoża został wyznaczony w oparciu o równanie [21]:

$$
z_{0}=\left(h-z_{d}\right) \exp \left(\frac{k}{\sqrt{0,5 C_{D h} \lambda_{F}}}\right)
$$

gdzie: $h$ - średnia wysokość budynku/budynków, $z_{d}$ - wartość przesunięcia płaszczyzny zerowej, $k$ - stała von Kármána $(0,4), C_{D h}$ - współczynnik oporu dla przeszkód $(0,8), \lambda_{F}-$ udział powierzchni frontowej budynku na powierzchni odniesienia.

W uproszczonej formie równanie można zapisać, jako:

$$
z_{0}=\left(h-z_{d}\right) \exp \left(-\frac{k}{\lambda_{F}}\right)
$$

Współczynnik powierzchni frontowej został wyznaczony, jako:

$$
\lambda_{F}=\frac{\sum_{\mathrm{i}=1}^{\mathrm{n}} A_{F_{i}}}{A_{T}}
$$

gdzie: $A_{F}$ - powierzchnia frontowa obiektu.

Wyznaczenie wartości parametru przesunięcia płaszczyzny zerowej nastąpiło na podstawie równania [21]:

$$
z_{d}=h\left(\lambda_{p}\right)^{0.6}
$$

gdzie: $\lambda_{p}$ - udział powierzchni zabudowanej.

Powierzchnia zabudowana została określona na podstawie równania, jako:

$$
\lambda_{p}=\frac{\sum_{\mathrm{i}=1}^{\mathrm{n}} A_{P_{i}}}{A_{T}}
$$

gdzie: $A_{T}$ - powierzchnia odniesienia. 
Według Gala i Ungera [18] ostatni z parametrów szorstkości podłoża, tj. porowatość w obrębie warstwy dachowej $(P)$ będący stosunkiem objętości swobodnego powietrza do objętości warstwy dachowej na powierzchni odniesienia może zostać wyznaczony za pomocą dwóch metod. W pierwszym przypadku, parametr uwzględnia kubaturę obiektów, powierzchnię odniesienia oraz wysokość budynków, co można zapisać w postaci ogólnej, jako:

$$
P_{h-c o n s t}=\frac{A_{T} h_{\text {const }}-V}{A_{T} h_{\text {const }}}
$$

gdzie: $A_{T}$ - powierzchnia odniesienia, $h_{\text {const }}$ - średnia wysokość obiektów w obrębie warstwy dachowej na obszarze opracowania, $V$ - suma kubatur obiektów.

W drugim przypadku, uwzględniana jest zmienna wysokość warstwy dachowej w obrębie powierzchni odniesienia. Dla każdej jednostki przestrzennej wysokość $h_{U C L}$ wyznaczana jest, jako wysokość najwyższego z obiektów na powierzchni odniesienia, co może zostać przedstawione $\mathrm{w}$ postaci:

$$
P_{h-v a r}=\frac{A_{T} h_{U C L}-V}{A_{T} h_{U C L}}
$$

gdzie: $h_{U C L}-$ wysokość najwyższego z obiektów na powierzchni odniesienia.

Metoda wyznaczania porowatości w obrębie warstwy dachowej bazująca na zmiennej wysokości obiektów, umożliwia uzyskanie dokładniejszych wyników badań, dlatego też została zastosowana w dalszej części opracowania.

\section{Wyznaczenie korytarzy przewietrzających na terenie Lodzi na podstawie oceny parametrów szorstkości terenu}

Określenie obszaru badań nastąpiło w oparciu o analizę literatury przedmiotu i obowiązujących dokumentów planistycznych. Wybór zachodniego fragmentu miasta został podyktowany dominującym zachodnim kierunkiem napływu powietrza do miasta $(65 \%)$, specyficznymi uwarunkowaniami fizjograficznymi oraz układem urbanistycznym. Zasięg badań został określony za pomocą następujących współrzędnych geograficznych:

- szerokość geograficzna: 51.693-51.811

- długość geograficzna: 19.319-19.451.

Kolejny etap obejmował pozyskanie danych przestrzennych o obiektach w postaci wektorowej z cyfrowej bazy danych ewidencji gruntów i budynków miasta, w Łódzkim Ośrodku Geodezji. Informacje obejmowały wymiary (wysokość, długość, szerokość) każdego z 38911 obiektów budowlanych na terenie opracowania.

Ze względu na fakt, iż struktura zabudowy oraz rodzaj pokrycia terenu w zasadniczy sposób wpływają na przepływ powietrza dokonano szczegółowej analizy zagospodarowania obszaru. Udział powierzchni zabudowanych na analizowanym obszarze wynosił 8,46\%. Dominującymi typami zabudowy były: zabudowa śródmiejska, wielorodzinna, jednorodzinna, jednorodzinna na kanwie osadnictwa wiejskiego, usługowa oraz przemysłowa. Największy udział stanowiły obiekty 1-3 kondygnacyjne (6,54\%) oraz 4-6 kondygnacyjne $(1,52 \%)$. Z uwagi na znaczenie terenów zieleni w systemie napowietrzania miasta w opracowaniu uwzględniono wszystkie obszary zieleni wysokiej. Ich udział wynosił 9,24\% powierzchni całkowitej. 
Ze względu na zróżnicowaną strukturę zabudowy występującą na analizowanym terenie niezbędnym było stworzenie nieregularnych grup obiektów. Grupowanie polegało na połączeniu pojedynczych, przylegających do siebie budynków w jeden obszar. W rezultacie powstało 19926 z 38911 obszarów poddanych dalszemu badaniu, dla których wyznaczono nowe parametry, tj. wysokość, szerokość, długość oraz powierzchnię frontową. Ostatni z parametrów został obliczony wykorzystując współrzędne prostokątne płaskie każdego wierzchołka obiektu, co można zapisać, jako:

$$
A_{F}=\left(y_{\max }-y_{\min }\right) h
$$

gdzie: $y_{\max }$ - współrzędna $y$ najdalej wysuniętego na północ wierzchołka obiektu od strony nawietrznej, $y_{\min }$ - współrzędna $y$ najdalej wysuniętego na południe wierzchołka obiektu od strony nawietrznej, $h$ - wysokość obiektu, bądź wartość wysokości dla najwyższego obiektu $\mathrm{w}$ grupie.

Ponadto, utworzonym obiektom/grupom obiektów przypisano powierzchnie odniesienia $\left(A_{T}\right)$ za pomocą algorytmu matematycznego Woronoja zaimplementowanego w oprogramowaniu QuantumGIS. Wyznaczone powierzchnie powstały na podstawie granic pomiędzy ścianami obiektów/grup obiektów, będących symetralnymi odcinków pomiędzy nimi. (Rys. 2)

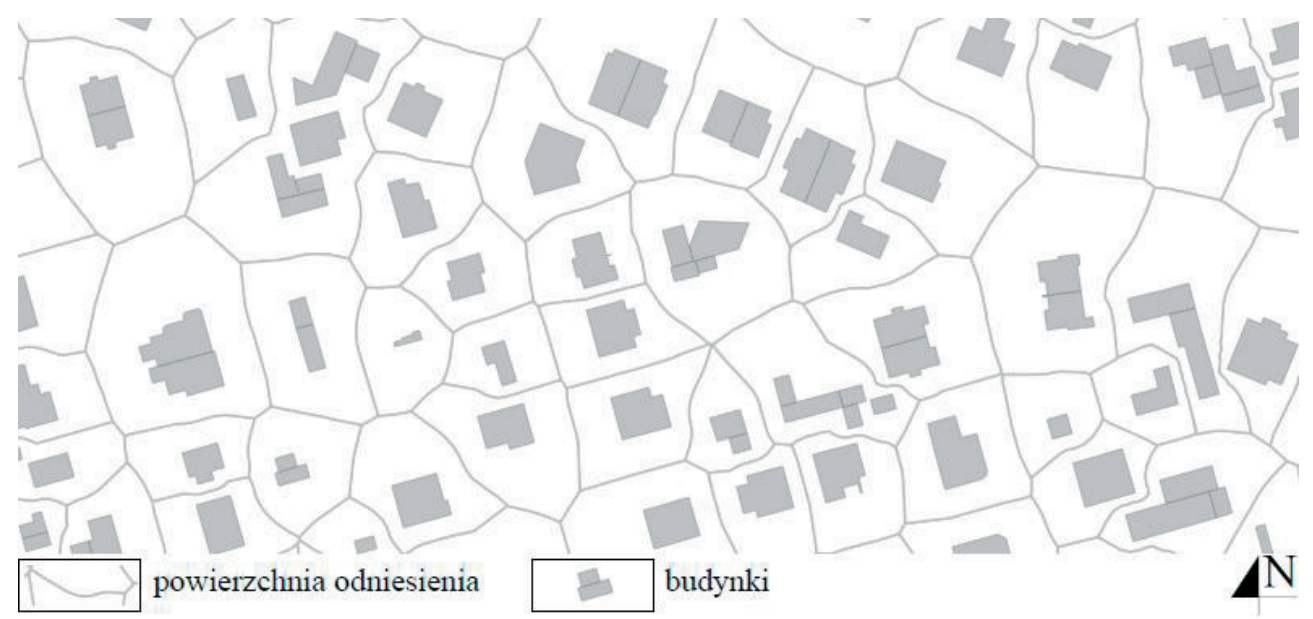

Rys. 2. Podział fragmentu obszaru opracowania na powierzchnie odniesienia

Następnie, na podstawie uzyskanych wyników zostały wyznaczone takie wskaźniki jak: udział powierzchni frontowej budynku ( $\lambda_{F}-$ na podstawie rów. 4) oraz udział powierzchni zabudowanej na powierzchni odniesienia ( $\lambda_{p}-$ na podstawie rów. 6). Średnie wartości wybranych parametrów zostały przedstawione w tab.1.

Tabela 1. Średnie wartości wybranych parametrów dla obszaru opracowania.

\begin{tabular}{cc}
\hline Parametr & Wielkość parametru średnia \\
\hline wysokość budynku (kondygnacja) & ok. 5 m $(1,71)$ \\
\hline powierzchnia frontowa budynku $\left[\mathrm{m}^{2}\right]$ & 186,99 \\
\hline powierzchnia budynku w rzucie $\left[\mathrm{m}^{2}\right]$ & 203,30 \\
\hline parametr powierzchni frontowej budynku & 0,07 \\
\hline udział powierzchni zabudowanej na powierzchni odniesienia $[\%]$ & 12,43 \\
\hline
\end{tabular}


Uzyskane wyniki umożliwiły obliczenie parametru przemieszczenia płaszczyzny zerowej $\left(z_{d}\right.$ - na podstawie rów. 5), porowatości w obrębie warstwy dachowej ( $P$ - na podstawie rów. 8), a tym samym określenie wskaźnika szorstkości podłoża $\left(z_{o}-\right.$ na podstawie rów. 2). Ich średnie wartości zostały przestawione w tab. 2.

Tabela 2. Średnie wartości parametrów przemieszczenia płaszczyzny zerowej $\left(z_{d}\right)$, porowatości $(P)$, szorstkości terenu $\left(z_{o}\right)$ dla analizowanego obszaru.

\begin{tabular}{cccc}
\hline \multirow{2}{*}{ Parametr } & \multicolumn{3}{c}{ Wielkość parametru } \\
\cline { 2 - 4 } & średnia & maksymalna & minimalna \\
\hline przemieszczenie płaszczyzny zerowej $\left(z_{d}\right)[\mathrm{m}]$ & 1,56 & 15,84 & 0,0035 \\
\hline porowatość $(P)$ & 0,87 & 1 & 0 \\
\hline szorstkość podłoża $\left(z_{o}\right)[\mathrm{m}]$ & 0,45 & 10,39 & 0 \\
\hline
\end{tabular}

Wyniki przeprowadzonych analiz wykazały zależność przepływu powietrza od struktury zabudowy, co jest widoczne w rozkładzie parametrów szorstkości terenu. Wartość pierwszego $\mathrm{z}$ nich, tj. przemieszczenia płaszczyzny zerowej $\left(z_{d}\right)$ waha się w przedziale od 0 do 16. (Rys. 3) Minima są przypisywane terenom otwartym (0). W przypadku zabudowy jednorodzinnej oraz przemysłowej jego wartość wynosi do 3 metrów gwarantując przepływ powietrza w tzw. warstwie dachowej. Maksymalne wartości charakteryzują zabudowę wielorodzinną blokową oraz kamieniczną. Zlokalizowane w zachodniej części miasta rozległe osiedla mieszkaniowe z lat 60-tych i 70-tych, z charakterystyczną pięcio- i dwunastokondygnacyjną zabudową stanowią istotną barierę dla napływającego powietrza.

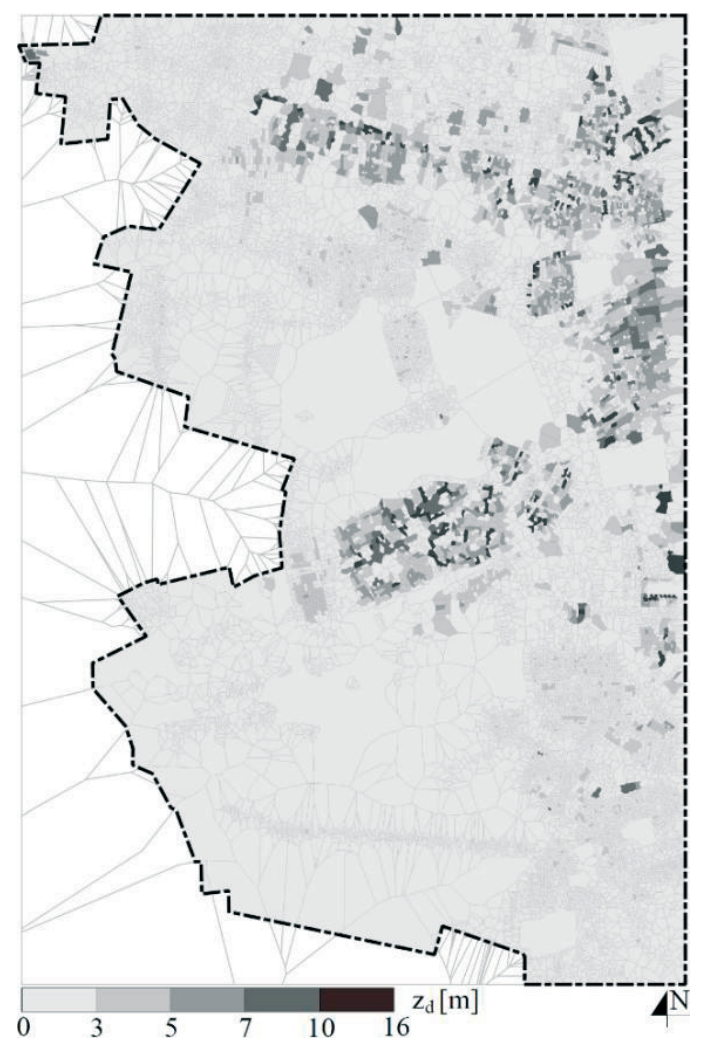

Rys. 3. Rozkład parametru przemieszczenia płaszczyzny zerowej $\left(z_{d}\right)$ dla wybranego fragmentu Łodzi 
Współczynnik porowatości dla zmiennej wysokości obiektów w obrębie warstwy dachowej obrazuje stosunek objętości swobodnego powietrza do objętości warstwy dachowej na powierzchni odniesienia. Tym samym umożliwia on wyznaczenie stopnia zwartości struktur zabudowanych. Wartość wskaźnika kształtuje się w przedziale od 0 do 1 . Najwyższa wartość (1) jest przypisywana terenom niezabudowanym, zaś najniższa (0) charakteryzuje gęstą, zwartą strukturę zabudowy, której udział wynosi $100 \%$ na powierzchni odniesienia. W przypadku zachodniego fragmentu Łodzi średnia wartość parametru wynosi 0,87. Wartości maksymalne są charakterystyczne dla powierzchni biologicznie czynnych, natomiast minima są obserwowane na terenach zabudowy śródmiejskiej. Niskie wartości parametru występują także na obszarach przemysłowych, ze względu na ich znaczną kubaturę oraz powierzchnię frontową przyczyniając się do spowolnienia napływu mas powietrza do miasta, a nawet zahamowania. (Rys. 4)

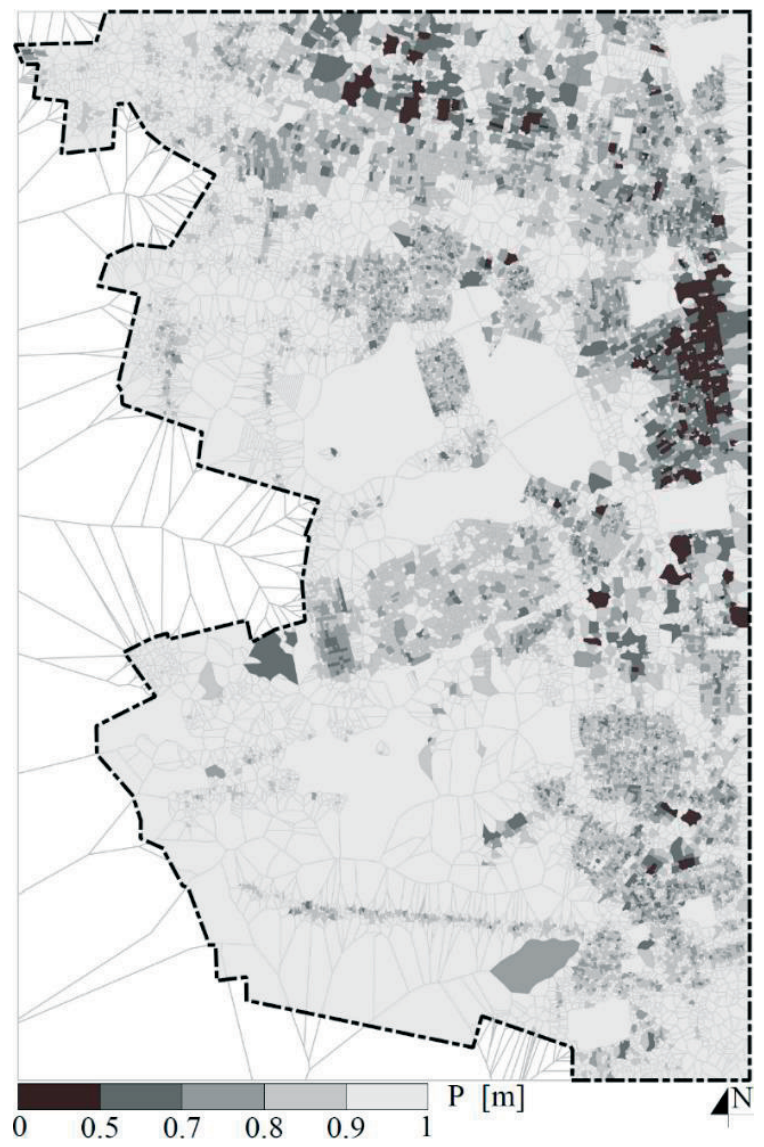

Rys. 4. Rozkład parametru porowatości w obrębie warstwy dachowej (P) dla wybranego fragmentu Łodzi

Ostatnim z analizowanych parametrów jest szorstkość terenu $\left(z_{o}\right)$. Jego rozkład jest zbliżony do rozkładu parametru przemieszczenia płaszczyzny zerowej $\left(z_{d}\right)$. Wartość wskaźnika waha się w przedziale od 0 do 10,39. Minima są charakterystyczne dla obszarów niezabudowanych, wartości do 1 metra są przypisywane terenom zabudowy jednorodzinnej oraz przemysłowej, zaś maksima występują na terenach zabudowy wielorodzinnej blokowej. (Rys. 5) 


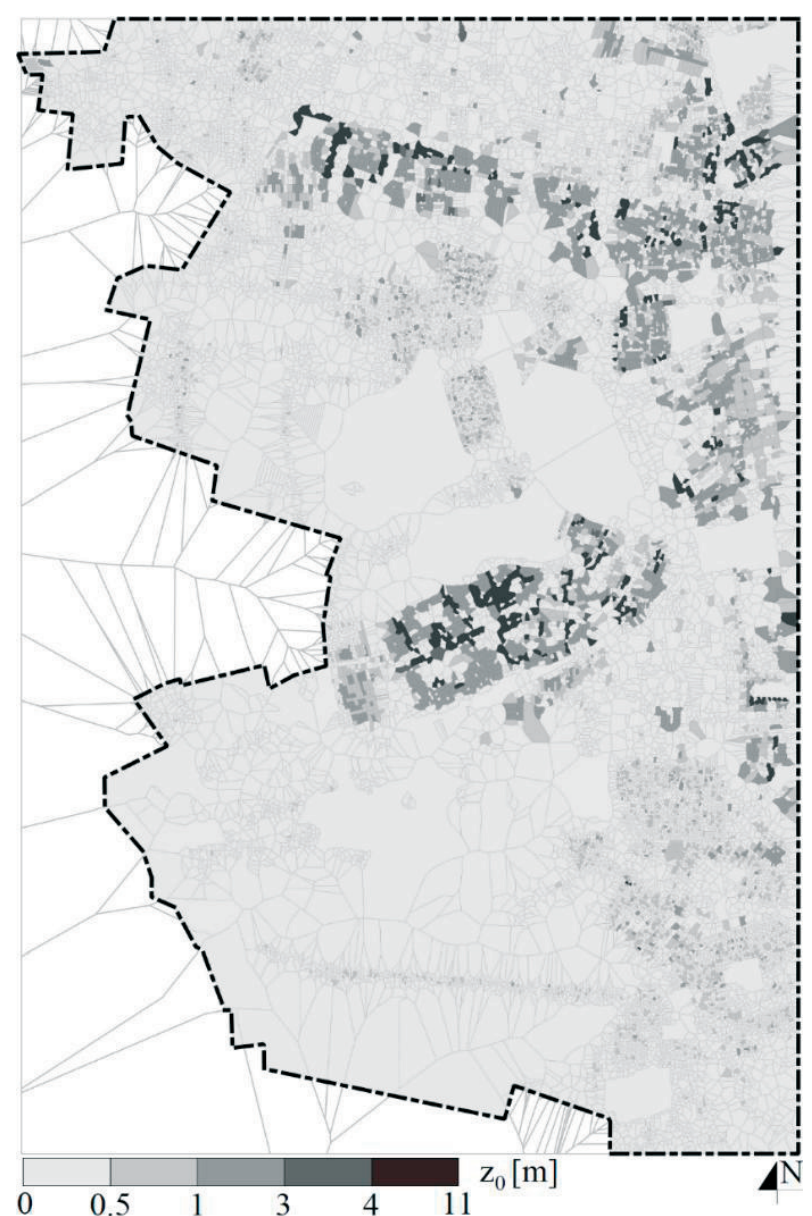

Rys. 5. Rozkład parametru szorstkości terenu (zo) dla wybranego fragmentu Łodzi

Ostatecznie, na podstawie opisanej procedury, wyników przeprowadzonych analiz oraz kryteriów prawidłowego funkcjonowania korytarzy przewietrzających sformułowanych przez Matzarakis'a oraz Mayer'a [8] wyznaczono osiem głównych obszarów swobodnego napływu mas powietrza dla zachodniego fragmentu Łodzi (Rys. 6). Według Studium Uwarunkowań i Kierunków Zagospodarowania Przestrzennego miasta Łodzi (2010) na obszarze opracowania powinny istnieć trzy korytarze przewietrzające miasto na osi wschód-zachód [9]. Maksymalna długość korytarza przewietrzającego wynosiła 7,8 km, zaś minimalna osiągnęła wartość $3,3 \mathrm{~km}$. Analizy obszaru wykazały możliwość występowania przepływów bocznych powietrza na obszarach stanowiących główne arterie komunikacyjne miasta oraz tereny kolejowe, co może przyczynić się do intensyfikacji procesu aeracji w mieście. Z drugiej strony, zostały zarysowane wyraźne bariery architektoniczne w postaci zwartych struktur zabudowy, które mogą powodować zahamowanie napływu powietrza do miasta z terenów peryferyjnych. Ponadto, zapisy dokumentów planistycznych na poziomie lokalnym umożliwiają rozbudowę/przebudowę oraz tworzenie nowych obiektów budowlanych na terenie opracowania. Oznacza to, że procesy inwestycyjne przyczynią się do zmniejszenia drożności korytarzy przewietrzających, a tym samym ich stopniowego zaniku. 


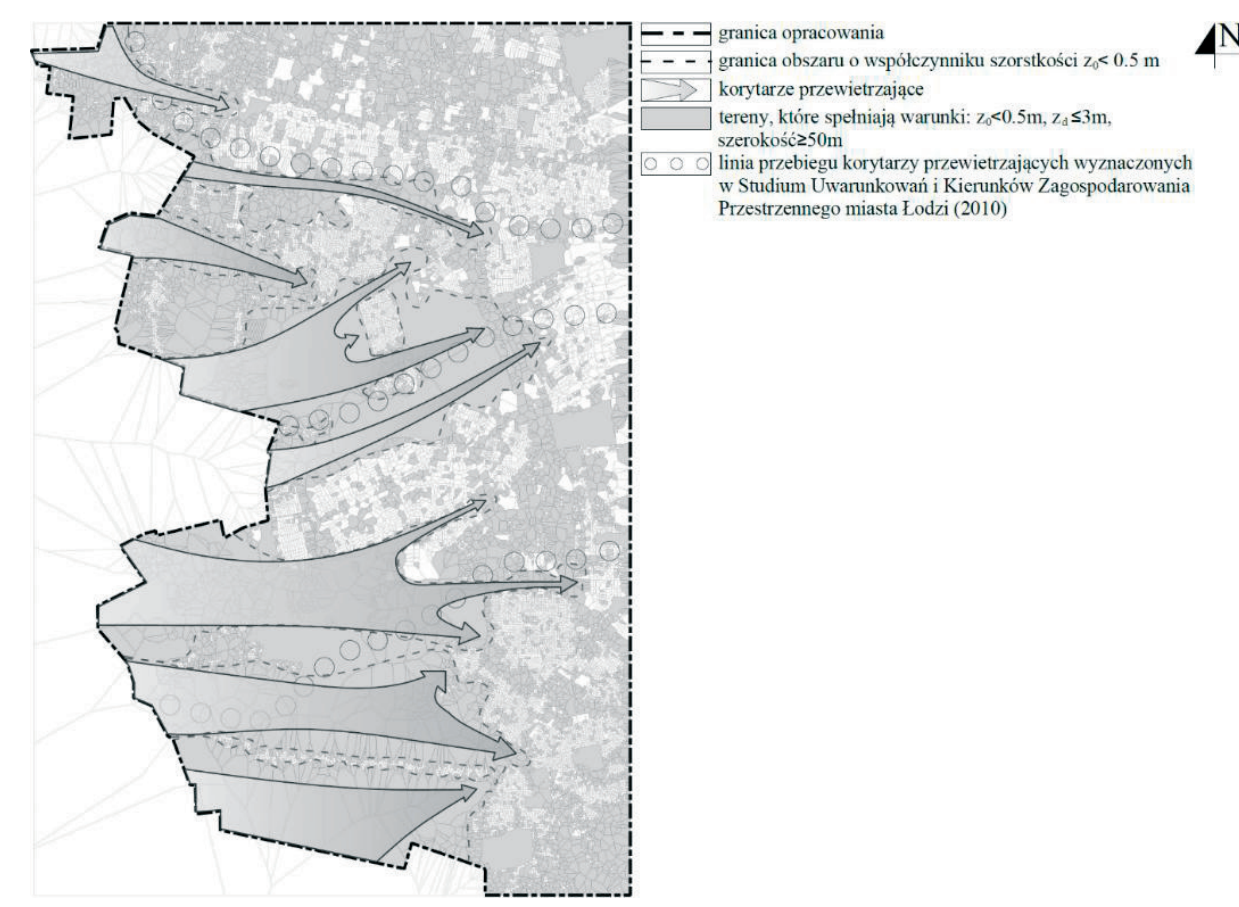

Rys. 6. Korytarze przewietrzające wyznaczone za pomocą metody morfometrycznej w Łodzi.

Za przykład może posłużyć teren zlokalizowany w obrębie ulic: SzczecińskaPodchorążych-Traktorowa-Rojna. Aktualne zagospodarowanie terenu, tj. zabudowa jednorodzinna szeregowa (ok. $9 \mathrm{~m}$ wysokości) występująca wzdłuż ciągów komunikacyjnych przebiegających z północy na południe, zabudowa wielorodzinna (ok. $15 \mathrm{~m}$ wysokości) w północno-wschodniej części obszaru przyczynia się do osłabienia przepływu powietrza już na wlocie do miasta. Jeżeli zezwoli się na dogęszczenie, budowę nowych obiektów w zachodniej oraz południowej części obszaru nastąpi zanik jednego z wyznaczonych korytarzy przewietrzających (wzdłuż ul. Rąbieńskiej).

Podobna sytuacja ma miejsce dla zabudowy wielorodzinnej blokowej zlokalizowanej w kwartale ulic: Maratońska-Płocka-Pienista-Janke, gdzie dominującym typem zabudowy są obiekty o średniej wysokości 9-15m. Przeznaczenie terenów biologicznie czynnych na cele inwestycyjne zmniejszy drożność korytarza przewietrzającego wzdłuż ulicy Maratońskiej, tworząc kolejną zwartą barierę architektoniczną dla napływających mas powietrza do miasta.

\section{Podsumowanie}

Zarówno analiza literatury przedmiotu, jaki i badania empiryczne autorów potwierdziły możliwość zastosowania procedury wyznaczania korytarzy przewietrzających na terenach zurbanizowanych. Pierwszy etap badań, tj. zastosowanie danych przestrzennych umożliwia łatwe i tanie pozyskanie informacji do prowadzonych badań. Zastosowanie metody morfometrycznej gwarantuje wysoką precyzję otrzymywanych wyników. Analiza parametrów szorstkości terenu, tj. przemieszczenia płaszczyzny zerowej $\left(z_{d}\right)$, porowatości w obrębie warstwy dachowej $(P)$ oraz szorstkości podłoża $\left(z_{o}\right)$, umożliwia wykluczenie terenów, na których przepływ powietrza zostaje zaburzony. Finalnie, uwzględniając parametry sformułowane przez Matzarakis'a oraz Mayer'a [8] możliwe jest wyznaczenie korytarzy przewietrzających. 
Pomimo tego, że tematyka prawidłowej aeracji miast jest coraz częściej podejmowana w badaniach empirycznych, to wciąż nie jest ona w wystarczający sposób uwzględniana w zakresie planowania przestrzennego. Dokumenty planistyczne mają charakter ogólny i nie zapewniają ochrony prawnej terenom stanowiącym korytarze przewietrzające miasta. Jedyną formą prawną zabezpieczenia tych terenów są akty prawa w postaci miejscowych planów zagospodarowania przestrzennego. Jednakże ich znikoma ilość w Łodzi prowadzi do degradacji obszarów otwartych, a tym samym do stopniowego zanikania korytarzy.

Analiza dokumentów na poziomie lokalnym wykazała, że obszary wytyczone w Studium Uwarunkowań i Kierunków Zagospodarowania Przestrzennego jako korytarze nie zapewniają napływu powietrza do centrum miasta. Na ich terenach zezwala się na tworzenie barier architektonicznych w postaci zabudowy wielo- oraz jednorodzinnej, blokującej przepływ powietrza. Przeprowadzone analizy wykazały, że zarówno obszary gęstej, zwartej zabudowy śródmiejskiej, jak i wielorodzinnej (bloki) w znacznym stopniu osłabiają przepływ powietrza w mieście. Dlatego też, w celu zapewnienia prawidłowego napływu powietrza do miast niezbędnym jest tworzenie aktów prawnych w postaci miejscowych planów zagospodarowania przestrzennego, uwzględniających podstawowe parametry korytarzy, takie jak: szorstkość podłoża, długość czy szerokość korytarzy. Dodatkowo, aby zwiększyć świadomość osób związanych z projektowaniem struktur miejskich powinny zostać opracowane szczegółowe wytyczne planistyczne uwzględniające zagadnienia aerodynamiki terenów zurbanizowanych. Ich sformułowanie powinno być poprzedzone analizami symulacyjnymi czy też badaniami w tunelu aerodynamicznym.

W pracy ograniczono się jedynie do wyznaczenia korytarzy w zachodnim sektorze miasta, biorąc pod uwagę dominujący kierunek wiatru. Jednak, aby w pełni określić możliwości aeracji należałoby zwrócić uwagę również na pozostałe kierunki umożliwiające napływ powietrza w sytuacji występowania bryzy miejskiej, związanej ze zjawiskiem miejskiej wyspy ciepła. Na podstawie przeprowadzonych badań należy stwierdzić, że istnieje pilna potrzeba stworzenia kompleksowego opracowania obejmującego zasięgiem cały obszar Łodzi oraz najbliższe tereny zurbanizowane, w celu określenia skuteczności przepływu powietrza w mieście. Analizy powinny uwzględniać zarówno aspekt mechanicznego oddziaływania wiatru, jak i zagadnienia dotyczące termiki obszaru Łodzi, ze względu na potęgujące się zjawisko miejskiej wyspy ciepła oraz związanej z nim cyrkulacji bryzowej. Ponadto należy podjąć współpracę z gminami ościennymi, w celu wypracowania wspólnej polityki przestrzennej zmierzającej do ochrony stref zasilania i regeneracji powietrza przed niekontrolowaną zabudową.

\section{Literatura}

1. Fortuniak K. Miejska Wyspa Ciepła. Wydawnictwo Uniwersytetu Łódzkiego, Łódź 2003.

2. $\quad$ Szymańska D. Urbanizacja na świecie. PWN, Warszawa 2007.

3. Laskowski L. Wybrane zagadnienia fizyki miasta. Centralny Ośrodek Informacji Budownictwa, Warszawa 1987.

4. Lewińska J. Klimat miasta. Zasoby, zagrożenia, ksztaltowanie. IGPiK Kraków 2000.

5. $\quad$ Landsberg H.E. The urban climate. Acad. Press. New York 1981.

6. Oke T.R. Boundary layers climates. London and New York, Routledge, 1987.

7. Barlag A.B., Kuttler W. The significance of country breezes for urban planning. Energy and Buildings 15-16, (1990/91) 291-297.

8. Matzarakis A., Mayer H. Mapping of urban air paths for planning in Munchen. Planning Applications of Urban and Building Climatology, Wissenschaftliche Berichte Institut fur Meteorologie und Klimaforschung Universitat Karlsruhe 16 (1992) 13-22. 
9. Wysmyk-Lamprecht B., Stobińska A., Jach K., Miłosz M. Opracowanie ekofizjograficzne sporzadzone na potrzeby studium uwarunkowań i kierunków zagospodarowania przestrzennego. Łódź 2007.

10. Kłysik K. Charakterystyka powierzchni miejskich Łodzi z klimatologicznego punktu widzenia. Folia Geographica Physica 3 (1998) 173-185.

11. Woźniak T. Drugie życie łódzkich rzek. [w:] Dobre praktyki wielkich miast. Unia Metropolii Polskich, Warszawa 2010.

12. Tomczak A. „Miasto w mieście”- ochrona struktury urbanistycznej posiadet wodnofabrycznych w Eodzi. Czasopismo Techniczne. Architektura 12 (2012) 69-75.

13. Kłysik K., Wibig J., Fortuniak K., Rembowski K., Fokczyński J., Podstawczyńska A. Atlas miasta Łodzi, Plansza X: klimat. Łódź 2002.

14. Liszewski S. Geografia urbanistyczna. Wydawnictwo Uniwersytetu Łódzkiego, Łódź 2003.

15. Davenport A.G., Grimmond C.S.B., Oke T.R., Wieringa J. Estimating the roughness of cities and sheltered country. Proceedings of the $12^{\text {th }}$ Conference on Applied Climatology, Boston American Meteorological Society (2000) 96-99.

16. Grimmond C.S.B., Oke T.R. Aerodynamic properties of urban areas derived from analysis of surface form. Journal of Applied Meteorology 38 (1999) 1262-1292.

17. Grimmond C.S.B., Oke T.R. Heat storage in urban areas: local scale observations and evaluation of a simple model. Journal of Applied Meteorology 38 (1999) 922-940.

18. Wieringa J., Davenport A.G., Grimond C.S.B., Oke T.R. New revision of Davenport roughness classification. Proc. of the 3rd European and African Conference on Wind Engineering, Eindhoven 2001.

19. Gal T., Unger J. Detection of ventilation paths using high-resolution roughness parameter mapping in a large urban area. Building and Environment 44 (2009) 198-206.

20. Suder A., Szymanowski M. Determination of ventilation channels in urban areas: a case study of Wroctaw (Poland). Pure and Applied Geophysics 171 (2014) 965-975.

21. Bottema M, Mestayer P.G. Urban roughness mapping - validation techniques and some first results. Journal of Wind Engineering and Industrial Aerodynamics 74-76 (1998) 163-173.

\title{
Detection of ventilation paths using morphometric method in the selected part of Lodz
}

\section{Anna Bochenek, Katarzyna Klemm}

Institute of Environmental Engineering and Building Installations, Faculty of Civil Engineering, Architecture and Environmental Engineering, Lodz University of Technology,e-mail: an.bochenek@wp.pl, katarzyna.klemm@p.lodz.pl

\begin{abstract}
The aim of the paper was an indication of potential ventilation paths which affect proper functioning of the cities aerial system. The research was conducted using the most popular method - morphometric for the sake of low cost data gathering and high precision of final results. Due to the wind's dominant direction, an analysis covered a windward part of Lodz. The first part of the research included an analysis of the basic roughness parameters such as: roughness length $\left(z_{o}\right)$, zero plane displacement height $\left(z_{d}\right)$ and porosity of the urban canopy layer $(P)$. Based on the obtained results and taking into account ventilation paths criteria eight areas were designated which provide a free flow of air to the city.
\end{abstract}

Keywords: ventilation channels, morphometric method, roughness parameters, spatial planning, urban areas. 
